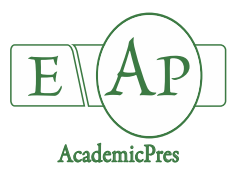

Akoumianaki-Ioannidou A et al. (2020)

Notulae Botanicae Horti Agrobotanici Cluj-Napoca 48(1):406-416

DOI:10.15835/nbha48111781

Research Article

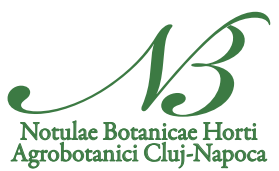

\title{
Cadmium effects on valerian (Valeriana officinalis $L$.$) morphology and$ Cd uptake in relation to substrate acidity/alkalinity
}

\author{
Anastasia AKOUMIANAKI-IOANNIDOU ${ }^{1}$, Zoe DALAKA², \\ Sofia MARKOU², Dafni IOANNOU², Nicholas K. MOUSTAKAS ${ }^{2 *}$ \\ ${ }^{1}$ Agricultural University of Athens, School of Plant Sciences, Department of Crop Science, Laboratory of Floriculture and Landscape \\ Architecture, Iera Odos 75, 11855 Athens, Greece; akouman@aua.gr \\ ${ }^{2}$ Agricultural University of Athens, School of Environment and Agricultural Engineering, Department of Natural Resources Development \\ and Agricultural Engineering, Laboratory of Soil Science and Agricultural Chemistry, Iera Odos 75, 118 55, Athens, Greece; \\ zoedalaka@gmail.com; sofiamarkou8@gmail.com;dioannou@aua.gr;nmoustakas@aua.gr(*correspondingauthor)
}

\begin{abstract}
Experiments were conducted on valerian (Valeriana officinalis L.) grown under glasshouse conditions to evaluate the effect of Cadmium $(\mathrm{Cd})$ on plant morphological characteristics and Cd uptake. Valerian plants were grown in pots containing a uniform mixture of either moderately acidic or slightly alkaline substrate consisting of peat and perlite $(1: 1 \mathrm{v} / \mathrm{v})$ over two periods. Pots were arranged in a completely randomized block design within two groups (moderately acid substrate and slightly alkaline substrate) with four $\mathrm{Cd}$ treatments $\left(0,1,2\right.$ and $\left.5 \mathrm{mg} \mathrm{Cd} \mathrm{L}^{-1}\right)$ and six replications per treatment. Cadmium was applied as $\mathrm{CdSO}_{4}{ }^{*} 8 / 3 \mathrm{H}_{2} \mathrm{O}$. No visual symptoms of toxicity or nutrient deficiency were attributed to $\mathrm{Cd}$ application irrespective of the growth stage or substrate in either experimental period. Cadmium did not affect the dry mass of shoots or roots. Cd concentration in both shoots and roots increased with increasing $\mathrm{Cd}$ application, indicating valerian to be a $\mathrm{Cd}$ accumulator with accumulation occurring mainly in the roots both in moderately acidic or slightly alkaline substrates. The amount of $\mathrm{Cd}$ extracted by Diethylene triamine penta acetic acid-triethanol amine (DTPATEA) increased with increasing $\mathrm{Cd}$ doses and significantly correlates with the $\mathrm{Cd}$ concentrations within the shoots and roots indicating that this extractant could be used to predict $\mathrm{Cd}$ concentrations within the plant parts.
\end{abstract}

Keywords: cadmium; DTPA-TEA; roots uptake; shoots uptake; valerian

\section{Introduction}

Cadmium is a heavy metal that remains in the soil for a much longer period than other heavy metals of the biosphere, so soil pollution tends to be permanent (Alloway, 1995); for example, the half-life of Cd in soil varies from 15-1100 years (Oliver, 1997). Heavy metals are not biodegradable but become converted to other forms that accumulate in the soil and plants and are washed away to only a small extent. The mobility of heavy metals within plants varies and generally depends on the particular metal, the type of plant, the plant organ and the age of the plant (Oliver, 1997). Cadmium is one of the most toxic heavy metals and moves relatively easily from the roots to the shoots (Tiller, 1989). Cadmium can enter the soil through mining, metallurgical activities, 
the plastics industry, the use of fossil fuels, the disposal of urban wastewater and especially through the use of phosphate fertilizers. The growth of industry in combination with the intensification of agriculture has caused a significant increase in cadmium pollution of the soil over the past century (Alloway, 1995). Its concentration in fertilizers ranges from $2-156 \mathrm{mg} \mathrm{kg}^{-1}$ (Tiller, 1989). Due to the many ways it can be found in soil, cadmium is considered one of the most serious toxic heavy metals. Cadmium is taken up by a variety of plants, but is not involved in any important biological function and is toxic (Andriano, 1986; Wagner, 1993). Cd adsorption/uptake depends on soil $\mathrm{pH}$, temperature, organic matter, cation exchange capacity, humidity, $\mathrm{Fe}$ and $\mathrm{Al}$ concentration, salt concentration and its relationship with competing elements (Jackson and Alloway, 1991). Several medicinal plants have a tendency to absorb higher amounts of $\mathrm{Cd}$ than other plants (Moustakas et al., 2011), while $\mathrm{Cd}$ competition with zinc $(\mathrm{Zn})$, iron (Fe) and manganese $(\mathrm{Mn})$ in the soil can cause deficiency of these micronutrients during plant growth (Adiloglu, 2002). Cd is highly mobile and toxic even at low concentrations in plant tissues (Andriano, 1986) and high concentrations of Cd in plant tissues can alter RNA synthesis, cause leaf rot, decrease photosynthesis rate, inhibit mouth opening in plants, and reduce the activity of various plant enzymes. Consequently, it can inhibit plant growth and reduce biomass (Kesseler and Brand, 1995; Salt et al., 1995; Gallego et al., 1996; Obata and Umebayashi, 1997). Cd enters the human body mainly through the gastrointestinal tract and lungs following exposure to contaminated air, water or food (Hallenbeck, 1984) to accumulate in vital organs, such as the kidneys. Extensive exposure to this element has been linked to pulmonary failure, kidney disorders and bone diseases. Finally, $\mathrm{Cd}$ has been implicated in the development of hypertension and various types of cancer (Bernard et al., 1986). However, even small amounts of $\mathrm{Cd}$ in the edible parts of the plant can have a significant impact on human health in the long run due to accumulation (Edmunds and Smedley, 1996).

Valeriana officinalis L. (common name valerian) is a perennial herb of the Fabaceae family and is native to Europe, North America and parts of Asia. Morphologically it is characterized by its numerous slender roots and rhizomes, light green foliage with linear to lanceolate, entire or dentate leaves and flowering stems 30-120 $\mathrm{cm}$. The white to pink flowers appears in July, in compound inflorescences, up to $10 \mathrm{~cm}$ in diameter. The plant blooms from May of the second year of cultivation (Strid and Kit, 1991). Valerian is mainly cultivated for its roots, which are harvested in autumn (September-October) from two-year-old plants. Valerian is a constituent of most medicines sold in pharmacies or health food stores as mild sedatives and sleep aids. Dried valerian roots are used for the preparation of herbal remedies to reduce stress, facilitate sleep, and relieve gastrointestinal disturbances (Foss and Houghton, 1997). Valerian was well known by ancient Greeks as a medicinal plant for the treatment of digestive problems, epilepsy and urinary tract infections (Foss and Houghton, 1997). It thrives in most soils, especially medium-textured or sandy soils with humus content (Bernath, 1997). Since Cd may enter the human food chain through medicinal plants, it is important to determine its potential toxicity and health risk in this plant category. Therefore, the aim of this study was to investigate the effect of $\mathrm{Cd}$ on valerian morphology and Cd uptake.

\section{Materials and Methods}

\section{Experimental conduction and design}

Pot experiments were conducted under unheated greenhouse conditions at the Agricultural University of Athens over two periods of approximately three to four months each. Valerian plants were grown in pots filled with a uniform mixture of peat and perlite $(1: 1 \mathrm{v} / \mathrm{v})$. Two types of peat were used: one moderately acidic and one slightly alkaline. For moderately acidic substrates, the "Baltica peat moss" of Klasmann-Deilmann with a pH of 4.5-5.6 was used. It is a light to moderately decomposed $(0-25 \mathrm{~mm})$ blonde peat with no addition of fertilizer or lime. The alkaline substrate comprised "Base substrate peat moss" of Klasmann-Deilmann with a balanced $\mathrm{pH}$ of 5.5-6.5. It is a natural blond peat with moderate structure $(0-25 \mathrm{~mm})$ and calcium oxide $(\mathrm{CaO})$ was added to adjust the $\mathrm{pH}$ to slightly alkaline. The organic matter and moisture content were $90 \%$ and 50 - 
$65 \%$ by weight, respectively. The perlite particles were 1 to $5 \mathrm{~mm}$ in diameter (Perloflor; ISOCON S.A., Athens, Greece). The expanded perlite can hold up to 3 times its weight in water while allowing for good root aeration; it has neutral $\mathrm{pH}$ and provides root protection against sudden temperature changes. The depth of substrate in the pots was $10 \mathrm{~cm}$. The $\mathrm{pH}$ of the moderately acidic substrate was 5.6 and that of the slightly alkaline substrate was 7.4. Pots were arranged in a completely randomized block design in two groups (moderately acid substrate and slightly alkaline substrate) with four Cd treatments $\left(0,1,2\right.$ and $\left.5 \mathrm{mg} \mathrm{Cd} \mathrm{L}^{-1}\right)$ and six replications per treatment. Cadmium was applied as $\mathrm{CdSO}_{4}{ }^{*} 8 / 3 \mathrm{H}_{2} \mathrm{O}$. The treatments, replications per treatment and the cultivation techniques were the same in both experimental periods.

\section{$1^{\text {st }}$ experiment}

The $1^{\text {st }}$ experiment started on February $21^{\text {st }}$ and ended on May $29^{\text {th }}, 2018$. Two-month- old seedlings of valerian (kindly sponsored by the "Vioma" estate, Greece) were transplanted on $21^{\text {st }}$ of February 2018 in plastic pots $(12 \times 12 \mathrm{~cm})$. On March $16^{\text {th }}$ began the addition of $20 \mathrm{ml}$ of each treatment per pot in both substrates and ended on May 29 $9^{\text {th }}$ 2018. Fertilization was performed three times, i.e. on April $3^{\text {rd }}$ and on May $5^{\text {th }}$ and $19^{\text {th }}$, using a commercial fertilizer (Nutrileaf-60) with $2 \mathrm{mg} \mathrm{N}, 2 \mathrm{mg} \mathrm{P}_{2} \mathrm{O}_{5}$, and $2 \mathrm{mg} \mathrm{K} 2 \mathrm{O}$ per pot (the content of Cd in the fertilizer was negligible). The total amount of $\mathrm{Cd}$ applied per pot throughout the cultivation period for both substrates was $200 \mathrm{ml}$ i.e. 10 applications, corresponding to $0.2 \mathrm{mg} \mathrm{Cd}$ for level $1 \mathrm{mg} \mathrm{L}^{-1}, 0.4 \mathrm{mg} \mathrm{Cd}$ for the level $2 \mathrm{mg} \mathrm{L}^{-1}$, and $1 \mathrm{mg} \mathrm{Cd}$ for the level $5 \mathrm{mg} \mathrm{L}^{-1}$.

\section{$2^{\text {nd }}$ experiment}

The $2^{\text {nd }}$ experiment began on $20^{\text {th }}$ of November 2018 and ended on $17^{\text {th }}$ of April 2019. Five-month- old seedlings of valerian (kindly sponsored by the "Vioma" estate, Greece) were transplanted on November $20^{\text {th }}$. On December $16^{\text {th }}$, began the addition of $20 \mathrm{ml}$ of each treatment to each pot at concentrations indicated above and ended on March $9^{\text {th }}$. Fertilization was performed once in both substrates on $16^{\text {th }}$ February using a 20-2020 commercial fertilizer. The total amount of $\mathrm{Cd}$ applied per pot was the same as that for the $1^{\text {st }}$ experiment. Throughout the experiments, the frequency of irrigation time varied according to the prevailing weather conditions. Pots were irrigated in such a way as to maintain the moisture at a soil matrix potential of $-100 \mathrm{~cm}$. This matrix potential ensured the maintenance of moisture in the substrate without the occurrence of leaching.

\section{Plant analysis}

The plants were cut in the neck area, carefully removed from the pots and divided into aerial (shoots) and underground (roots) plant parts, the fresh weight of which was measured immediately. The dry weight of both plant parts was measured after drying to a constant weight in an oven at $60^{\circ} \mathrm{C}$. Dry samples were ground in a stainless-steel Wiley mill and passed through a $150 \mu \mathrm{m}$ plastic sieve to ensure uniformity. Porcelain beakers were loaded with $0.5 \mathrm{~g}$ dry ground tissue smaller than $150 \mu \mathrm{m}$ in diameter from each pot and ashed at $550{ }^{\circ} \mathrm{C}$ for 4 hours. Upon completion of combustion the residue was dissolved in $5 \mathrm{ml}$ of $6 \mathrm{~N} \mathrm{HCL}$. The suspension was filtered into $100 \mathrm{ml}$ volumetric flasks and made up to volume with deionized water. Cd was determined by flame atomic absorption spectrophotometry at $213.9 \mathrm{~nm}$ using an air-acetylene flame. Cd uptake by shoots and roots of valerian was calculated by multiplying the dry weight of shoots and roots by the corresponding Cd concentration and expressed as $\mathrm{mg} \mathrm{Cd}$ per plant and pot. The sum of shoot and root uptake corresponded to the plant Cd uptake.

\section{Substrate analysis}

Samples of air-dried substrate from each pot at the end of each experiment were passed through a 500 $\mu \mathrm{m}$ plastic sieve and analysed for extractable Cd using the diethylene triamine penta acetic acid-triethanol amine (DTPA-TEA), method of Lindsay and Norvell (1978). 


\section{Statistical analysis}

The influence of $\mathrm{Cd}$ application on valerian morphology, plant $\mathrm{Cd}$ uptake and the concentration of $\mathrm{Cd}$ extracted from the soil by DTPA-TEA were evaluated by analysis of variance (ANOVA), using STATISTICA (StatSoft, 2008). All data were subjected to Duncan's Multiple Range Test to determine statistical significance of the effects due to treatments with Cd.

\section{Results and Discussion}

Macroscopic examination of treated plants did not reveal visible symptoms of toxicity or nutrient deficiency over the application range of $0-5 \mathrm{mg} \mathrm{Cd} \mathrm{kg}^{-1}$ in plants grown either in moderately acidic or slightly alkaline substrate in either experimental period. Similarly, no differences in plant height were attributed to $\mathrm{Cd}$ application irrespective of the growth stage or substrate in either experimental period.

\section{$I^{\text {st }}$ experimental period}

In the moderately acidic and the slightly alkaline substrate, shoot and root dry matter was not affected by Cd doses up to $5 \mathrm{mg} \mathrm{L}^{-1}$. In the moderately acidic substrate $\mathrm{Cd}$ concentration in shoots and roots increased with $\mathrm{Cd}$ doses greater than 2 and $1 \mathrm{mg} \mathrm{L}^{-1}$, respectively (Figure 1). In the slightly alkaline substrate $\mathrm{Cd}$ concentration in shoots and roots increased with Cd doses greater than $1 \mathrm{mg} \mathrm{L}^{-1}$ (Figure 1). Consequently, $\mathrm{Cd}$ uptake by valerian increased with $\mathrm{Cd}$ doses, independent of substrate acidity (Figures 3, 4). Cd concentration in the roots of plants grown in either substrate was higher than that of the shoots at each level of application (Figure 1).

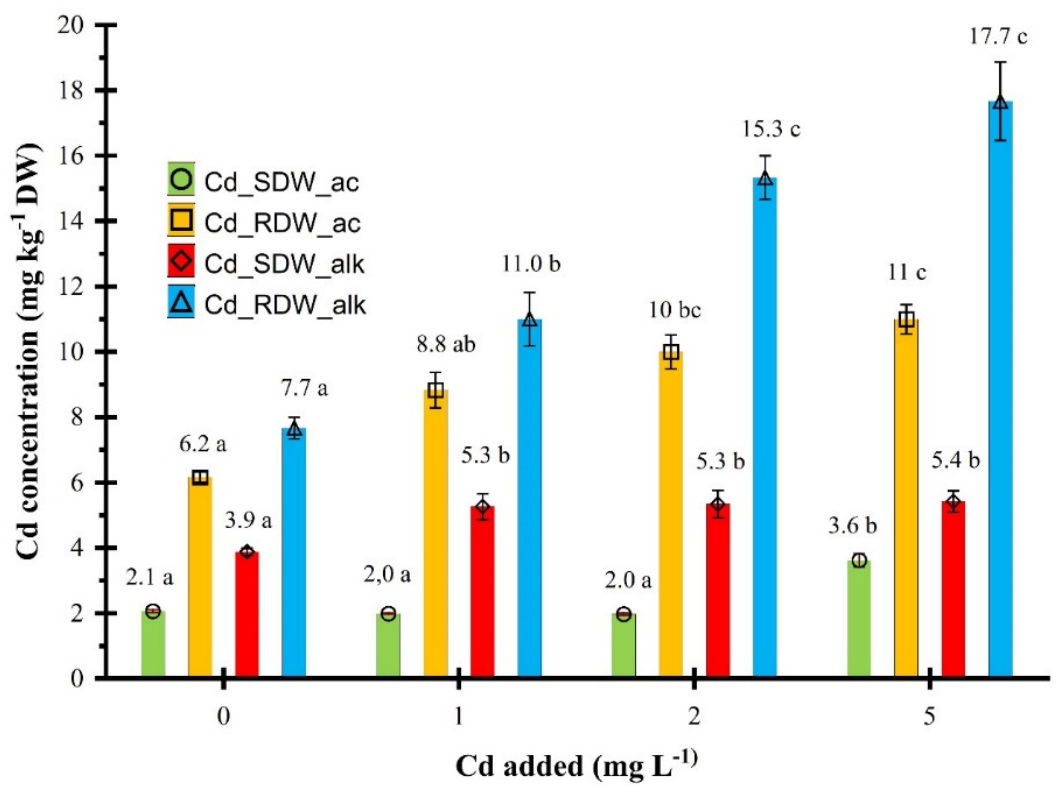

Figure 1. Effect of Cd application on the Cd concentration in shoots (Cd_SDW_ac) and roots (Cd_RDW_ac) of valerian plants grown in a moderately acidic substrate and in shoots (Cd_SDW_alk) and roots (Cd_RDW_alk) of valerian plants grown in slightly alkaline substrate during the $1^{\text {st }}$ experimental period

Note: Numbers shown are means \pm SE $(n=6)$. Different letters following the mean values above bars with the same colour indicate significant differences between treatments, according to Duncan's multiple range test at $\mathrm{p} \leq 0.05$ 
410

\section{$2^{\text {nd }}$ experimentalperiod}

In both the moderately acidic and the slightly alkaline substrate, shoot and root dry matter was not affected by $\mathrm{Cd}$ doses up to $5 \mathrm{mg} \mathrm{L}^{-1}$. In the moderately acidic substrate $\mathrm{Cd}$ concentration in shoots and roots increased with $\mathrm{Cd}$ doses greater than 2 and $1 \mathrm{mg} \mathrm{L}^{-1}$, respectively (Figure 2). In the slightly alkaline substrate $\mathrm{Cd}$ concentration in shoots and roots increased with Cd doses greater than 1 and $2 \mathrm{mg} \mathrm{L}^{-1}$, respectively (Figure 2). Hence, $\mathrm{Cd}$ uptake by valerian increased with $\mathrm{Cd}$ doses, independent of substrate acidity (Figures 5, 6). Cd concentration in the roots of valerian grown in either substrate was higher than that in the shoots at Cd doses greater than $2 \mathrm{mg} \mathrm{L}^{-1}$ (Figure 2).

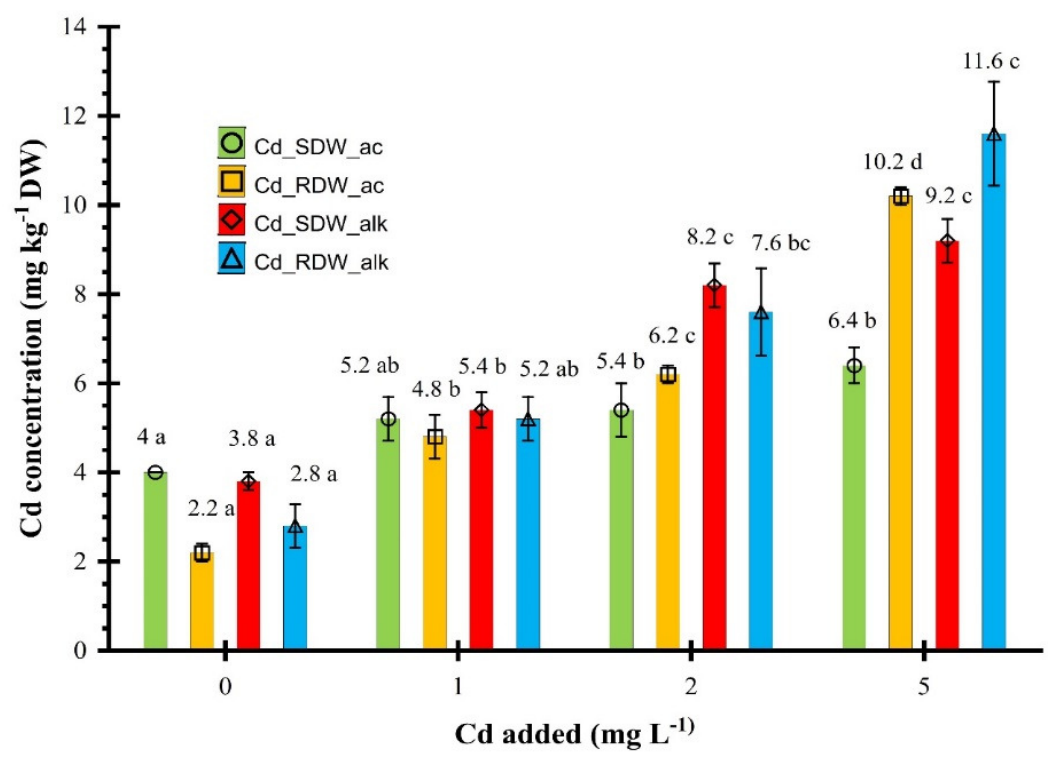

Figure 2. Effect of $\mathrm{Cd}$ application on the $\mathrm{Cd}$ concentration in shoots (Cd_SDW_ac) and roots (Cd_RDW_ac) of valerian plants grown in a moderately acidic substrate and in shoots (Cd_SDW_alk) and roots (Cd_RDW_alk) of valerian plants grown in slightly alkaline substrate during the $2^{\text {nd }}$ experimental period.

Note: see Figure 1

In both experimental periods shoot, root and total $\mathrm{Cd}$ uptake by valerian plants increased with increasing Cd application (Figures 3, 4, 5, 6). These results are in accordance with those reported by Akoumianaki-Ioannidou et al. (2019) for hyssop. Moustakas et al. (2001) and Akoumianakis et al. (2008) reported that $\mathrm{Cd}$ application increased $\mathrm{Cd}$ concentrations in the leaves of lettuce, radish and cucumber, and in endive and rocket, respectively.

In control treatments during the $1^{\text {st }}$ experimental period, the $\mathrm{Cd}$ concentration in shoots and roots was 2.1 and $6.2 \mathrm{mg} \mathrm{kg}^{-1}$, respectively for plants grown in moderately acidic substrate, and 3.9 and $7.7 \mathrm{mg} \mathrm{kg}^{-1}$, respectively for plants grown in slightly alkaline substrate (Figure 1 ). In control treatments during the $2^{\text {nd }}$ experimental period, the $\mathrm{Cd}$ concentration in shoots and roots was 4.0 and $2.2 \mathrm{mg} \mathrm{kg}^{-1}$, respectively for plants grown in moderately acidic substrate, and 3.8 and $2.8 \mathrm{mg} \mathrm{kg}^{-1}$, respectively for plants grown in slightly alkaline substrate (Figure 2). These values are much higher than those for Cd extracted by DTPA-TEA (Table 1). These findings in both experimental periods are particularly noteworthy since they indicate significant accumulation of $\mathrm{Cd}$ by valerian independent of substrate acidity. In addition, no growth inhibition was detected even though considerable $\mathrm{Cd}$ concentrations were found within the plants. Overall, therefore, valerian can be considered a Cd accumulating plant, like hyssop, rocket, endive, lettuce, spinach, turnip grass, celery and cabbage (Bingham et al., 1983; Davis 1984; Akoumianakis et al., 2008; Akoumianaki-Ioannidou et al., 2019). 


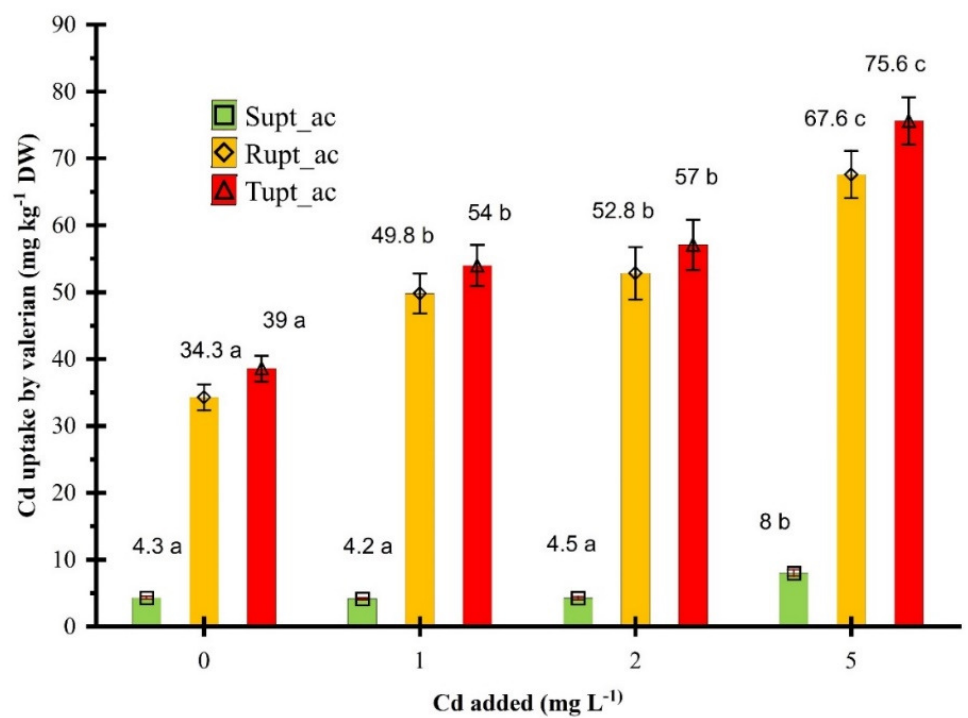

Figure 3. Effect of Cd application on Cd uptake by shoots (SUpt), Cd uptake by roots (RUpt) and total $\mathrm{Cd}$ uptake (TUpt) by valerian plants cultivated in moderately acid substrate during the $1^{\text {st }}$ experimental period.

Note: see Figure 1

Table 1. Effect of applied Cd on Cd extracted by DTPA-TEA during two experimental periods

\begin{tabular}{|c|c|c|c|c|}
\hline & \multicolumn{2}{|c|}{$1^{\text {st }}$ experimental period } & \multicolumn{2}{c|}{$2^{\text {nd }}$ experiment period } \\
\hline Cd added & $\begin{array}{c}\text { Moderately acidic } \\
\text { substrate }\end{array}$ & $\begin{array}{c}\text { Slightly alkaline } \\
\text { substrate }\end{array}$ & $\begin{array}{c}\text { Moderately acidic } \\
\text { substrate }\end{array}$ & $\begin{array}{c}\text { Slightly alkaline } \\
\text { substrate }\end{array}$ \\
\hline $\mathrm{mg} \mathrm{L}^{-1}$ & \multicolumn{4}{|c|}{$\mathrm{mg} \mathrm{kg}^{-1}$} \\
\hline 0 & $0.03 \mathrm{a}$ & $0.02 \mathrm{a}$ & $0.14 \mathrm{a}$ & $0.12 \mathrm{a}$ \\
\hline 1 & $0.14 \mathrm{~b}$ & $0.12 \mathrm{~b}$ & $0.29 \mathrm{~b}$ & $0.38 \mathrm{~b}$ \\
\hline 2 & $0.27 \mathrm{c}$ & $0.19 \mathrm{c}$ & $0.32 \mathrm{~b}$ & $0.56 \mathrm{c}$ \\
\hline 5 & $0.68 \mathrm{~d}$ & $0.53 \mathrm{~d}$ & $0.66 \mathrm{c}$ & $0.89 \mathrm{~d}$ \\
\hline
\end{tabular}

Column means followed by the same letter are not significantly different, according to Duncan's multiple range test, at $\mathrm{p} \leq 0.05$

The amount of Cd extractable by DTPA-TEA in the moderately acidic substrate ranged from 0.1 to 0.7 $\mathrm{mg} \mathrm{kg}^{-1}$ and from 0.3 to $0.9 \mathrm{mg} \mathrm{kg}^{-1}$ for the $1^{\text {st }}$ and $2^{\text {nd }}$ experimental period, respectively (Table 1 ). In the slightly alkaline substrate the amount of Cd extractable by DTPA-TEA, ranged from 0.1 to 0.5 and from 0.4 to $0.9 \mathrm{mg}$ $\mathrm{kg}^{-1}$ for the $1^{\text {st }}$ and the $2^{\text {nd }}$ experimental period, respectively (Table 1 ). The concentrations of Cd extractable by DTPA-TEA in both periods were lower than the maximum tolerable levels ( 1.6 to $6 \mathrm{mg} \mathrm{kg}^{-1}$ ) for Cd in agricultural soils in various countries proposed by Kabata-Pendias and Pendias (1992). Cd addition to the substrate led to a significant increase in extractable Cd by DTPA-TEA in both substrates and both periods, as indicated in Figures 7 and 8.

Regression analysis between the amount of $\mathrm{Cd}$ in the substrate that was extractable by DTPA-TEA and total Cd uptake by valerian independently of the experimental period, indicated that this extractant could be used effectively to predict Cd uptake in valerian grown in this substrate (Table 2,3). Moustakas et al. (2001), Akoumianakis et al. (2008) and Akoumianaki-Ioannidou et al. (2019) reported that DTPA-TEA could also be used to predict $\mathrm{Cd}$ uptake by lettuce, radish, cucumber, endive, rocket and hyssop. 
Akoumianaki-Ioannidou A et al. (2020). Not Bot Horti Agrobo 48(1):406-416.

412

Table 2. Regression summary for dependent variable Total Cd uptake (TUpt) by valerian plants grown either in moderately acidic or slightly alkaline substrate in the $1^{\text {st }}$ experimental period and Cd extracted by DTPA-TEA

\begin{tabular}{|c|c|c|c|c|c|c|c|c|c|c|c|}
\hline \multicolumn{12}{|c|}{$1^{\text {st }}$ experimental period } \\
\hline \multicolumn{6}{|c|}{ Moderately acid substrate } & \multicolumn{6}{|c|}{ Slightly alkaline substrate } \\
\hline \multirow{4}{*}{$\mathrm{N}=24$} & \multirow{2}{*}{\multicolumn{5}{|c|}{$\begin{array}{c}\text { Regression summary for dependent Var: } \\
\text { TUpt_ac } \\
R=0.826 R^{2}=0.682 \text { Adiusted } R^{2}=0.668\end{array}$}} & \multicolumn{6}{|c|}{ Regression summary for $\mathrm{d}$} \\
\hline & & & & & & \multirow{3}{*}{$N=24$} & $\mathrm{R}=0$ & $82 \mathrm{R}^{2}=0$ & 613 Adju & $\mathrm{ed} \mathrm{R}^{2}=$ & \\
\hline & \multicolumn{5}{|c|}{$\begin{array}{c}\mathrm{F}(1.22)=47.37 \mathrm{p}<0.000 \text { Std.Err of estimate: } \\
8.78\end{array}$} & & \multicolumn{5}{|c|}{$\begin{array}{c}\mathrm{F}(1.22)=34.85 \mathrm{p}<0.000 \text { Std.Err of estimate: } \\
13.18\end{array}$} \\
\hline & Std.Err & $b$ & Std.Err & $\mathrm{t}(22)$ & $\begin{array}{c}\mathrm{p}- \\
\text { value }\end{array}$ & & Std.Err & $\mathrm{b}$ & Std.Err & $\mathrm{t}(22)$ & $\begin{array}{c}\mathrm{p}- \\
\text { value }\end{array}$ \\
\hline Intercept & & 42.528 & 2.688 & 15.824 & 0.00 & Intercept & & 40.318 & 4.016 & 10.040 & 0.00 \\
\hline Cd_ac_soil & 0.120 & 49.301 & 7.163 & 6.883 & 0.00 & Cd_alk_soil & 0.133 & 82.184 & 13.922 & 5.903 & 0.00 \\
\hline
\end{tabular}

Table 3. Regression summary for dependent variable Total Cd uptake (TUpt) by valerian plants grown either in moderately acidic or slightly alkaline substrate in the $2^{\text {nd }}$ experimental period and Cd extracted by DTPA-TEA

\begin{tabular}{|c|c|c|c|c|c|c|c|c|c|c|c|}
\hline \multicolumn{12}{|c|}{$2^{\text {nd }}$ Experimental period } \\
\hline \multicolumn{6}{|c|}{ Moderately acid substrate } & \multicolumn{6}{|c|}{ Slightly alkaline substrate } \\
\hline \multirow{4}{*}{$\mathrm{N}=24$} & \multirow{2}{*}{\multicolumn{5}{|c|}{$\begin{array}{l}\text { Regression summary for dependent Var: } \\
\text { TUpt_ac } \\
R=0.881 \mathrm{R}^{2}=0.776 \text { Adjusted } \mathrm{R}^{2}=0.763\end{array}$}} & \multicolumn{6}{|c|}{ Regression summary for dependent Var: } \\
\hline & & & & & & \multirow{3}{*}{$\mathrm{N}=24$} & & $948 R^{2}=0$ & 99 Adjus & $\mathrm{R}^{2}=08$ & \\
\hline & \multicolumn{5}{|c|}{$\begin{array}{c}\mathrm{F}(1.22)=62.37 \mathrm{p}<0.000 \text { Std.Error of estimate: } \\
16.58\end{array}$} & & \multicolumn{5}{|c|}{$\begin{array}{c}\mathrm{F}(1.18)=160.47 \mathrm{p}<0.000 \text { Std.Error of estimate: } \\
13.97\end{array}$} \\
\hline & Std.Err & $\mathrm{b}$ & Std.Err & $\mathrm{t}(22)$ & $\begin{array}{c}\mathrm{p}- \\
\text { value }\end{array}$ & & Std.Err & $\mathrm{b}$ & Std.Err & $\mathrm{t}(22)$ & $\begin{array}{c}\mathrm{p}- \\
\text { value }\end{array}$ \\
\hline Intercept & & 36.651 & 7.494 & 4.891 & 0.00 & Intercept & & 40.975 & 6.184 & 6.626 & 0.00 \\
\hline $\mathrm{Cd}$ ac soil & 0.112 & 147.313 & 18.653 & 7.898 & 0.00 & $\mathrm{Cd}$ alk soil & 0.075 & 138.527 & 10.936 & 12.668 & 0.00 \\
\hline
\end{tabular}

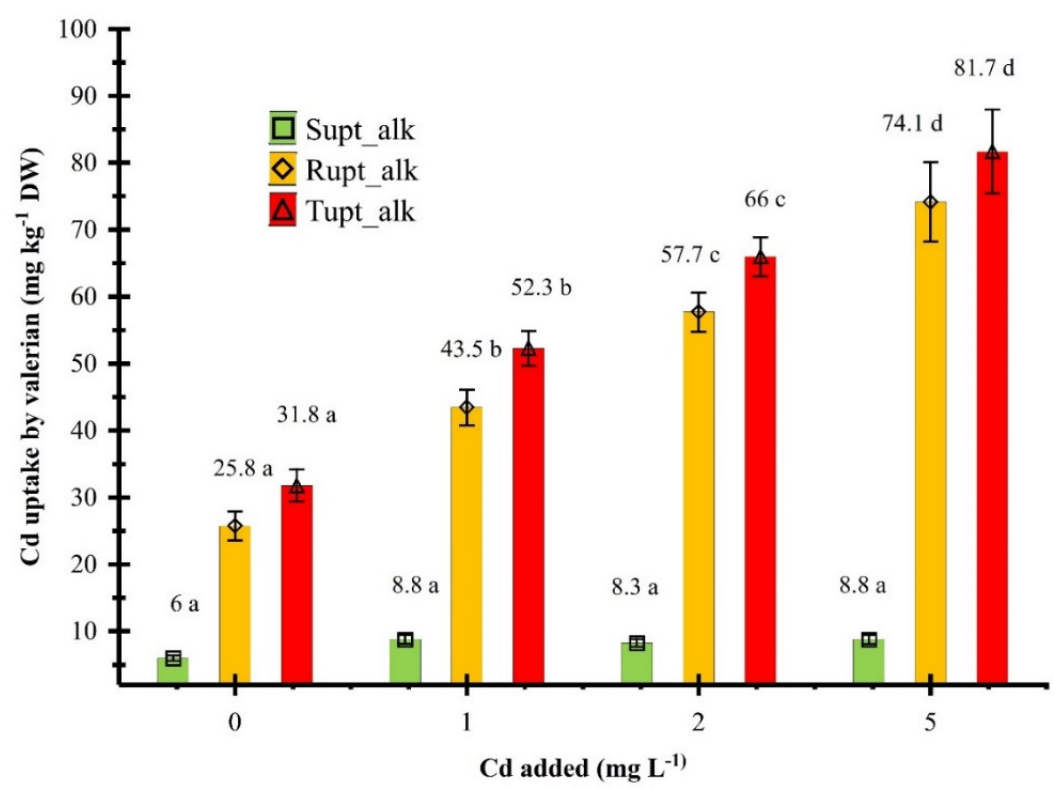

Figure 4. Effect of Cd application on Cd uptake by shoots (SUpt), Cd uptake by roots (RUpt), and total $\mathrm{Cd}$ uptake (TUpt) by valerian plants cultivated in slightly alkaline substrate during the $1^{\text {st }}$ experimental period.

Note: see Figure 1 


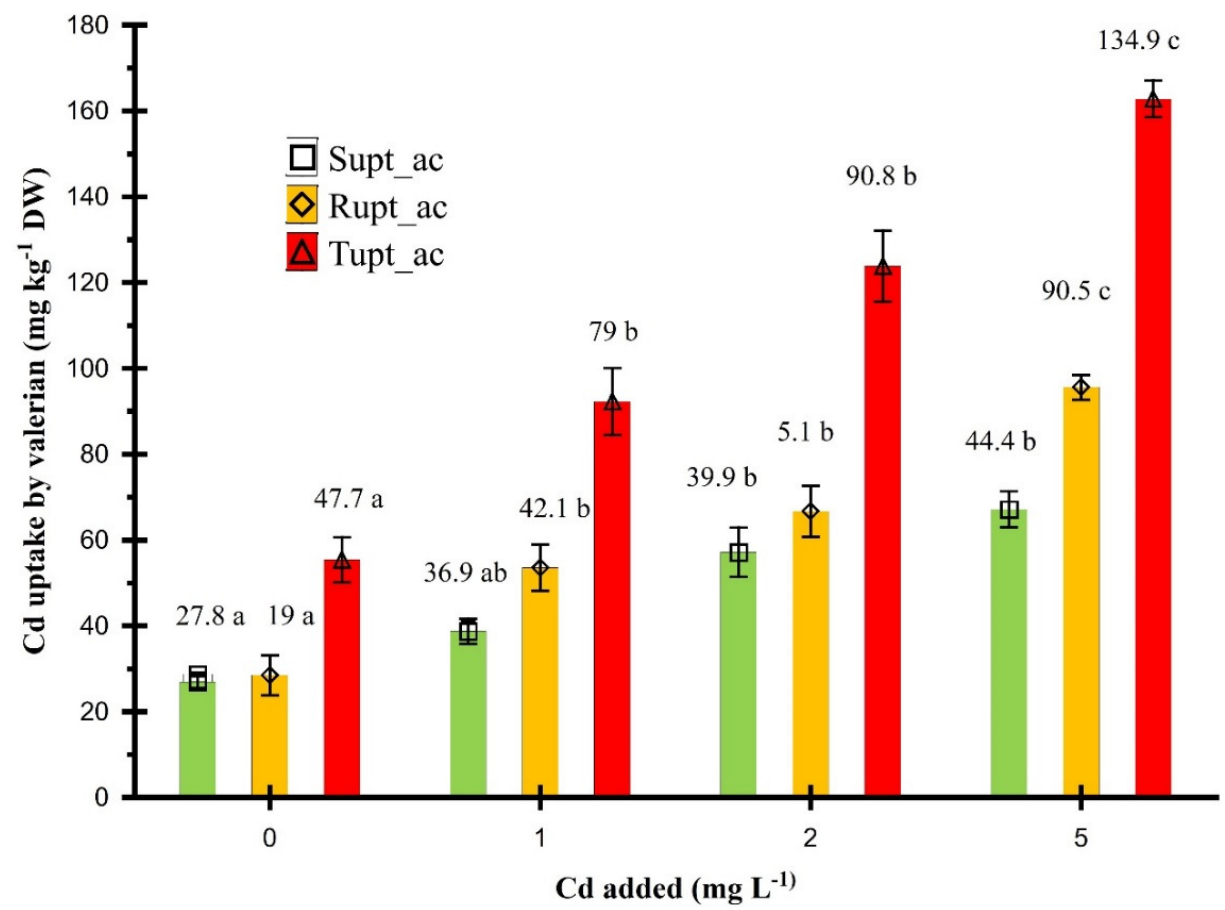

Figure 5. Effect of Cd on Cd uptake by shoots (SUpt), Cd uptake by roots (RUpt), and total Cd uptake (TUpt) by valerian plants cultivated in moderately acid substrate during the $2^{\text {nd }}$ experimental period. Note: see Figure 1

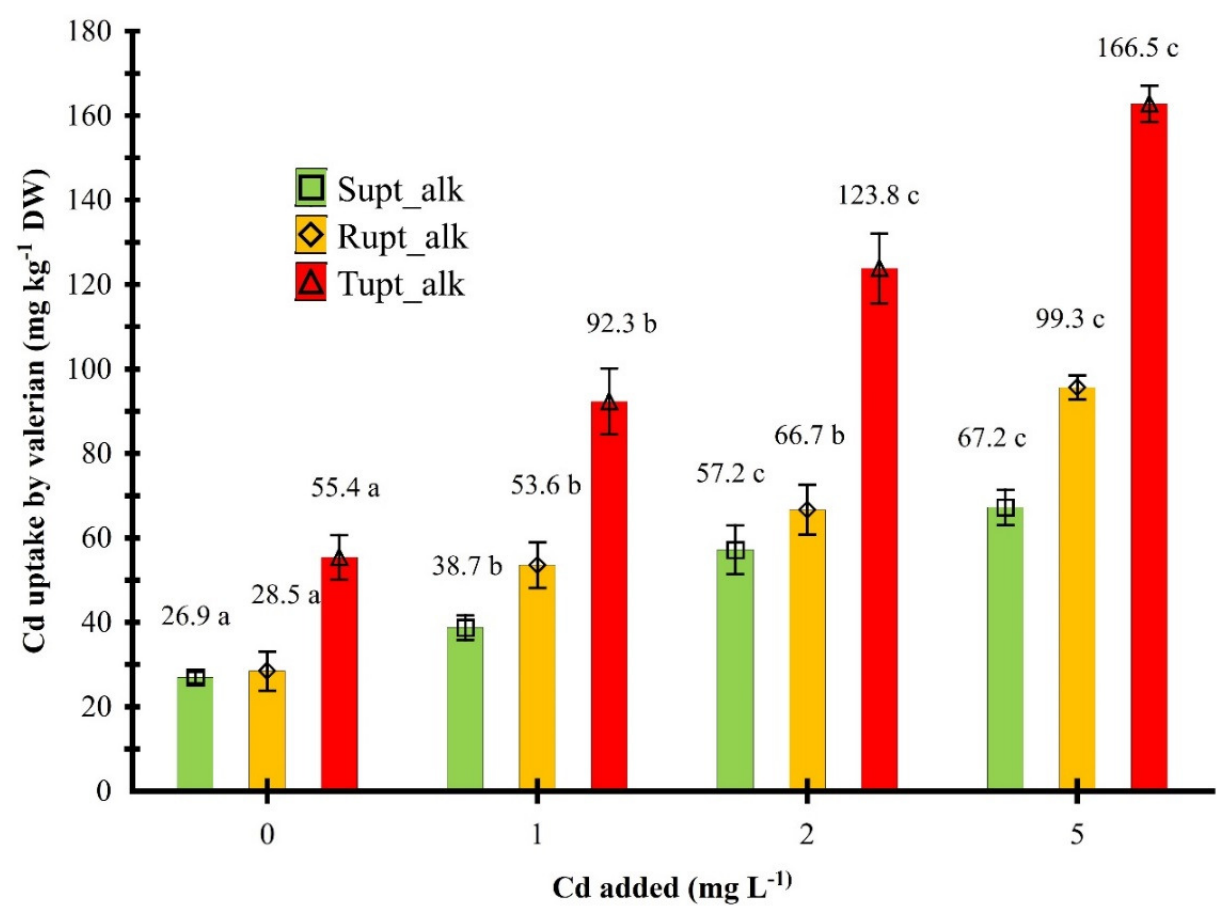

Figure 6. Effect of Cd on Cd uptake by shoots (SUpt), Cd uptake by roots (RUpt), and total Cd uptake (TUpt) by valerian plants cultivated in slightly alkaline substrate during the $2^{\text {nd }}$ experimental period. Note: see Figure 1 


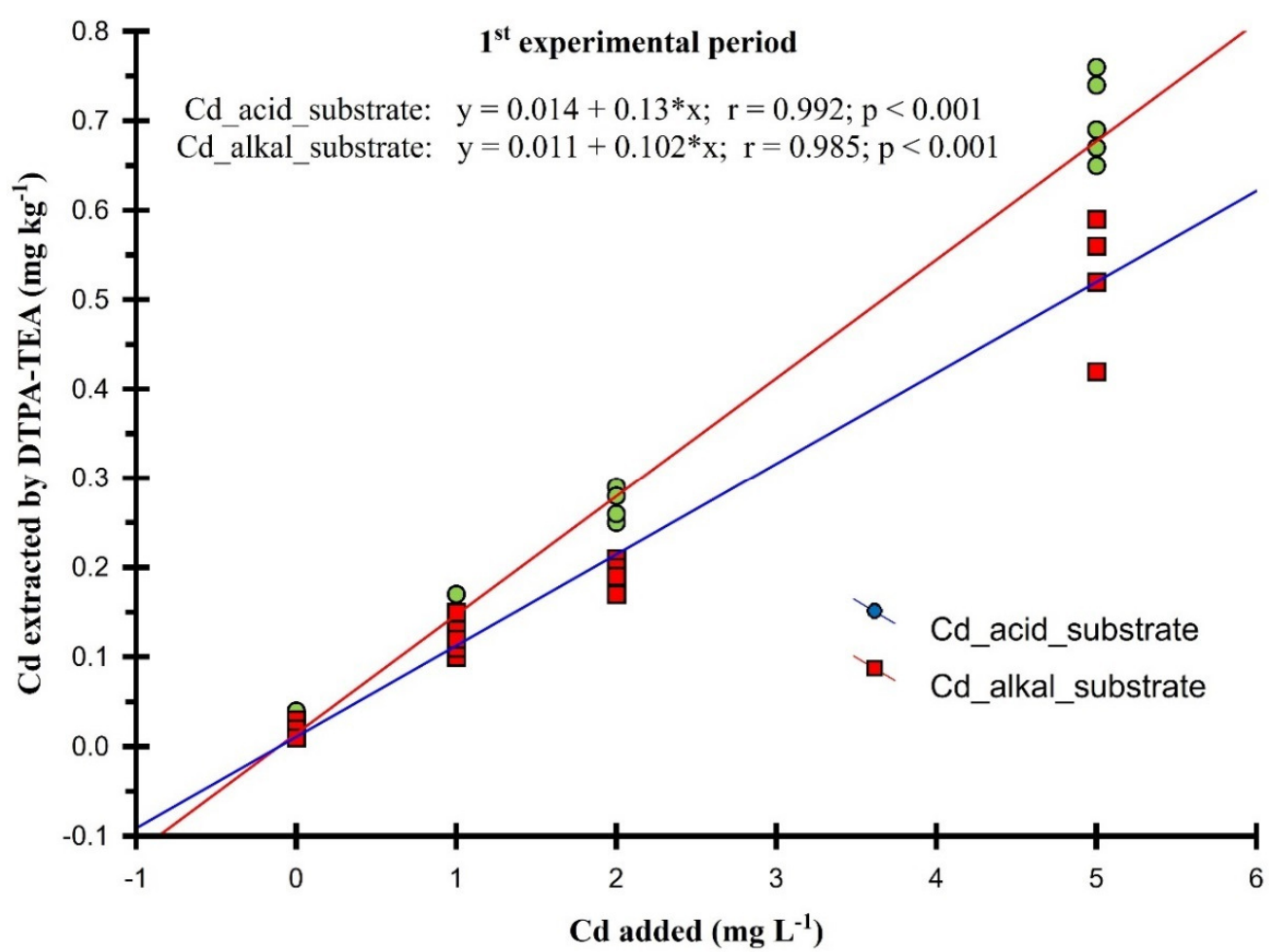

Figure 7. Extractable Cd by DTPA-TEA as affected by $\mathrm{Cd}$ additions ( $1^{\text {st }}$ experimental period)

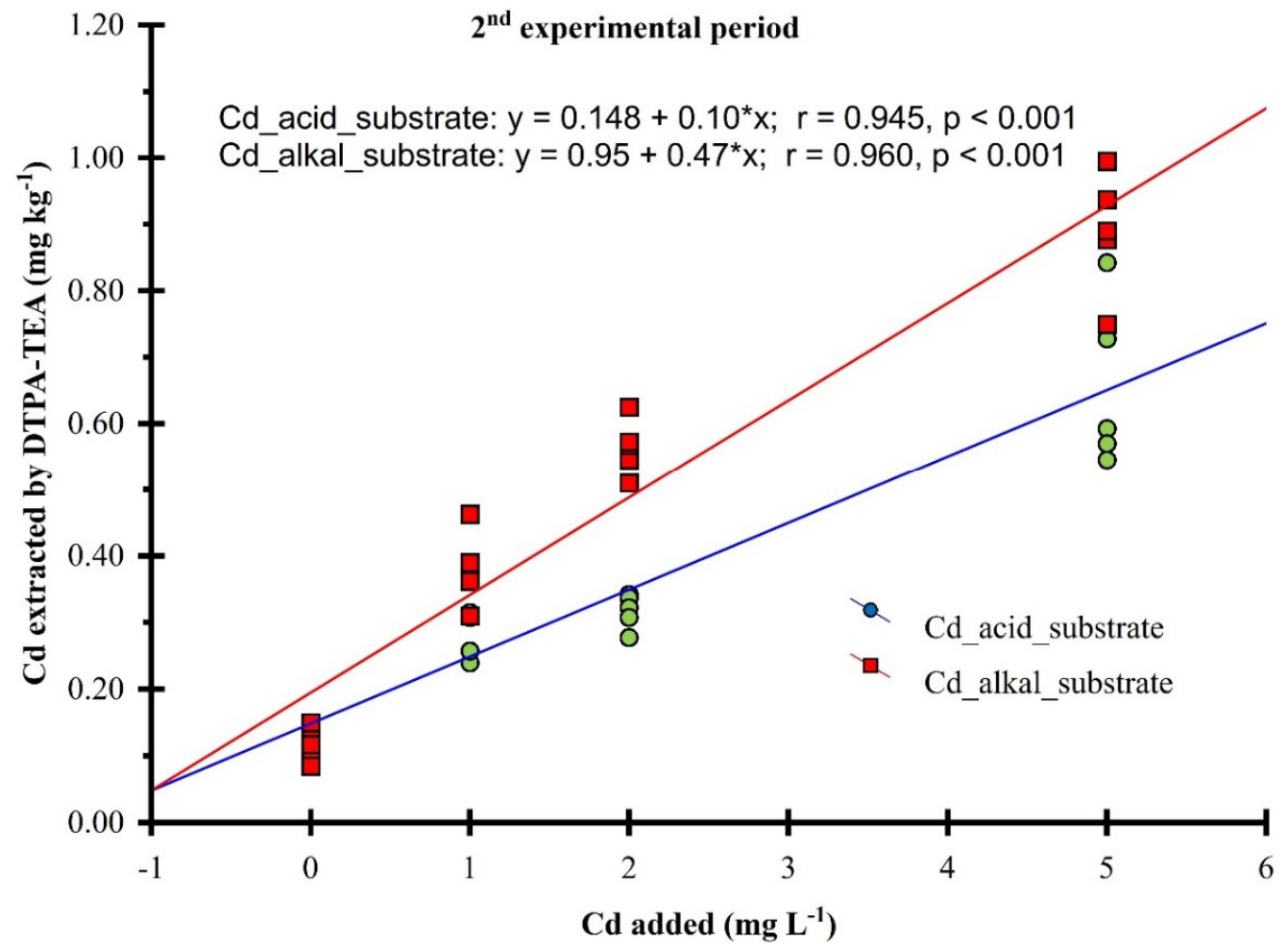

Figure 8. Extractable Cd by DTPA-TEA as affected by Cd additions ( $2^{\text {nd }}$ experimental period) 


\section{Conclusions}

Valerian plants did not exhibit visual symptoms of toxicity or deficiency by the application of up to 5 mg Cd L $\mathrm{L}^{-1}$ substrate. Valerian plant height as well as shoot and root dry weight were not affected by $\mathrm{Cd}$

application. Cadmium uptake by shoots and roots of valerian increased with increasing Cd application irrespective of substrate acidity. Cd extraction by DTPA-TEA could be used to predict Cd uptake by valerian.

\section{Conflict of Interests}

The authors declare that there are no conflicts of interest related to this article.

\section{References}

Adiloglu A (2002). The effects of zinc (Zn) application on uptake of cadmium (Cd) in some cereal species. Archives Agronomy Soil Science 48:553-556.

Akoumianaki-Ioannidou A, Kapama D, Mpantouna A, Moustakas NK (2019). Cadmium effects on hyssop (Hyssopus officinalis L.) morphology and Cd uptake in relation to substrate acidity/alkalinity. Notulae Botanicae Horti Agrobotanici ClujNapoca 47(4):1394-1399.

Akoumianakis KA, Passam HC, Barouchas PE, Moustakas NK (2008). Effect of cadmium on yield and cadmium concentration in the edible tissue of endive (Cichorium endivia L.) and rocket (Eruca sativa Mill.). International Journal of Food Agriculture and Environment 6(3\&4):201-209.

Alloway BJ (1995). Cadmium. In: Alloway BJ (Ed). Heavy metals in soils. Blackie Academic and Professional, Glasgow pp 121151.

Andriano DC (1986). Trace elements in the terrestrial environment. Springer-Verlag, Berlin, Germany.

Bernard AM, Lauwerys R, Foulkes EC (1986). Effects of cadmium exposure in humans. Handbook of experimental pharmacology Vol 80. Berlin: Springer Verlag pp 135-177.

Bernath J (1997). Cultivation of valerian. In: Houghton PJ (Ed). Valerian-The genus Valeriana. Harwood Academic Publishers pp 81-86.

Bingham FT, Strong JE, Sposito G (1983). Influence of chloride salinity on cadmium uptake by Swiss Chard. Soil Science 135:160-165.

Davis RD (1984). Cadmium-a complex environmental problem. Part 2. Cadmium in sludges used as fertilizer. Experientia 40:17-234.

Edmunds WM, Smedley PL (1996). Ground water geochemistry and health: An overview. In: Appleton JD, Funge R, McCall, GJH (Eds). Environmental Geochemistry and Health. Spec Publ London. No 113: Geological Society of Science pp 91105.

Foss R, Houghton PJ (1997). Valeriana products. In: Houghton PJ (Ed). Valerian-the genus Valeriana. Harwood Academic Publishers pp 135-136.

Gallego SM, Benavídes MP, Tomaro ML (1996). Effect of heavy metal ion excess on sunflower leaves: Evidence for involvement of oxidative stress. Plant Science 121(2):151-159.

Hallenbeck WH (1984). Human health effects of exposure to cadmium. Experiencia 40:136-142.

Jackson AP, Alloway BJ (1991). The bioavailability of cadmium to lettuce and cabbage in soils previously treated with sewage sludges. Plant and Soil 132:179-186.

Kabata-Pendias A, Pendias H (1992). Trace elements in soils and plants. $2^{\text {nd }}$ Edition, Levis Publ Inc. pp 365.

Kesseler A, Brand M (1995). The mechanism of the stimulation of state 4 respiration by cadmium in potato tuber (Solanum tuberosum) mitochondria. Plant Physiology Biochemistry 33(4):519-528.

Lindsay WL, Norvell WA (1978). Development of a DTPA soil test for zinc, iron, manganese and copper. Soil Sci Society America Journal 31:421-428. 
Akoumianaki-Ioannidou A et al. (2020). Not Bot Horti Agrobo 48(1):406-416.

416

Moustakas NK, Akoumianakis KA, Passam HC (2001). Cadmium accumulation and its effect on yield of lettuce, radish, and cucumber. Communications in Soil Science and Plant Analysis 32:1793-1802.

Obata H, Umebayashi M (1997). Effects of cadmium on mineral nutrient concentrations in plants differing in tolerance for cadmium. Journal Plant Nutrition 20(1):97-105.

Oliver MA (1997). Soil and human health: a review. Eurasian Journal Soil Science 48:573-592.

Salt DE, Prince RC, Pickering IJ, Raskin I (1995). Mechanisms of cadmium mobility and accumulation in Indian mustard. Plant Physiology 109(4):1427-1433.

STATISTICA (2008). StatSoft, Inc. Tulsa, OK, USA.

Strid A, Tan K (1991). Mountain flora of Greece. Vol. II. Edinburgh University Press. Edinburgh.

Tiller KG (1989). Heavy metals in soils and their environmental significance. Advances Soil Science 9:113-142.

Wagner GJ (1993). Accumulations of cadmium in crop plants and its consequences to human health. Advances Agronomy 51:173-213.
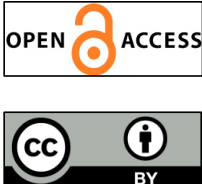

The journal offers free, immediate, and unrestricted access to peer-reviewed research and scholarly work. Users are allowed to read, download, copy, distribute, print, search, or link to the full texts of the articles, or use them for any other lawful purpose, without asking prior permission from the publisher or the author.

License - Papers published in Notulae Botanicae Horti Agrobotanici Cluj-Napoca are Open-Access, distributed under the terms and conditions of the Creative Commons Attribution (CC BY 4.0) License.

(c) Articles by the authors; UASVM, Cluj-Napoca, Romania. The journal allows the author(s) to hold the copyright/to retain publishing rights without restriction. 